\title{
Origin of well-rounded gravels in glacial deposits from Brøggerhalvøya, northwest Spitsbergen: potential problems caused by sediment reworking in the glacial environment
}

\author{
DAVID HUDDART, MATTHEW R. BENNETT, MICHAEL J. HAMBREY, NEIL F. GLASSER and KEVIN CRAWFORD
}

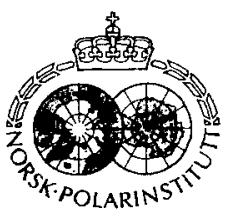

Huddart, D., Bennett, M. R., Hambrey, M. J., Glasser N. F. \& Crawford. K. 1998: Origin of well-rounded gravels from Brøggerhalvøya, northwest Spitsbergen: potential problems caused by sediment reworking in the glacial environment. Polar Research 17(1), 61-69.

Well-rounded gravels are described from moraine-mound complexes, diamicton forefields and modern englacial thrusts at the margins of four glaciers on the northern side of Brøggerhalvøya, northwest Spitsbergen. Their shape characteristics are compared with modern and fossil glacigenic, modern beach and Early Weichselian beach gravels from this peninsula. The best discriminators of the well-rounded gravels have been found to be the percentage-frequency roundness histograms, the roundness mid-point and roundness range diagrams and the sphericity-roundness plots. It is concluded that the gravels have been derived by englacial thrusting from Early Weichselian or last interglacial beaches in the inner parts of the fjord and in the low level cirques when sea level reached at least $50 \mathrm{~m}$ a.s.l. and deposited the beach gravels. The discrimination between gravel in basal diamictons, proglacial outwash and modern beaches is difficult as the reworking has resulted in little particle shape change. The potential major problem caused by reworking in the glacial environment is emphasised, especially when clast shape comparisons from modern environments to older sediments are used.

David Huddart, School of Education and Community Studies, I. M. Marsh Campus, Liverpool John Moores University, Barkhill Road, Liverpool L17 6BD, U.K.; Matthew R. Bennett, School of Earth and Environmental Sciences, University of Greenwich, Medway Towns Campus, Pembroke, Chatham Maritime, Kent ME4 4AW, U.K.; Michael J. Hambrey*, Neil Glasser and Kevin Crawford†, School of Biological and Earth Sciences, Liverpool John Moores University, Byrom Street, Liverpool L3 3AF, U.K.

\section{Introduction}

The shape of clasts in sedimentary environments is commonly used to help infer the processes of deposition. As part of a wider project concerned with moraine formation and sedimentation at high-arctic, polythermal glaciers (Hambrey \& Huddart 1995; Huddart \& Hambrey 1996; Bennett et al. 1996a and b; Hambrey et al. 1997) data on clast shape from a range of glacial facies of known origin was routinely collected. This dataset of 172 samples from these polythermal glaciers adds to the growing reference material on clast shape which can be used to aid the interpretation of sediments of unknown origin and was reported in Bennett et al. (1997). During the data collection, a facies consisting of very wellsorted and rounded pebble/cobble gravels was

\footnotetext{
* now at the Centre for Glaciology, Institute of Geography and Earth Sciences, University of Wales, Aberystwyth, Ceredigion Sy 23 3DB, U.K.

$\dagger$ now at Liverpool Hope University, Hope Park, Liverpool L16 9JD, U.K.
}

recorded on the forefields of glaciers on the northern side of Brøggerhalvøya (Fig. 1). The gravels are visually distinctive (Fig. $2 \mathrm{~A}$ and $\mathrm{B}$ ) and different from any other facies sampled. They are colloquially described as "egg gravels" (Bennett et al. 1997) but they are referred throughout this paper as well-rounded gravels. The aim of this paper is to demonstrate the distinctive nature of this facies and offer an explanation for its formation and incorporation into both modern and Neoglacial maxima glacigenic sediments in the investigated area.

\section{Morphological occurrence of the well-rounded gravels}

The well-rounded gravels occur in three morphological settings within the glacier forefields of Brøggerhalvøya: (1) as pods within the morainemound complexes which mark the Neoglacial maxima; (2) as distinct ridges trending across flat, diamicton and gravel forefields; and (3) within 


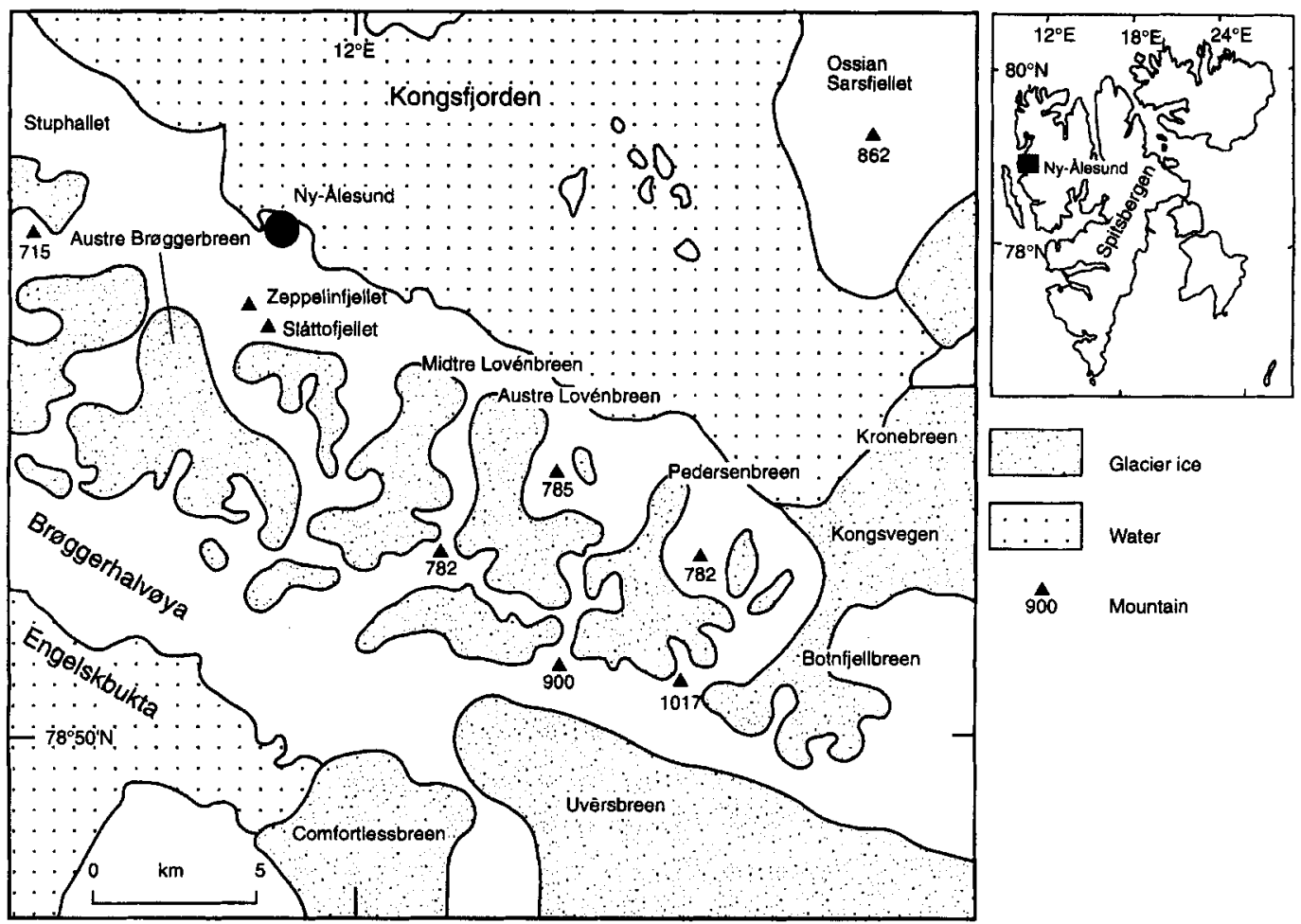

Fig. 1. Location of the high-arctic valley glaciers in this study. Altitudes are in metres above sea level.

englacial thrusts outcropping on the glacier surface. Within the moraine-mound complexes wellrounded gravels can be found as pods, up to $10 \mathrm{~m}$ across (Fig. 2A), within the diamicton which is the dominant facies within the moraine complexes. The moraine-mound complexes have been interpreted as the product of englacial and proglacial thrusting in response to flow compression at a polythermal ice margin (Sollid \& Sørbel 1988; Hambrey \& Huddart 1995; Bennett et al. 1996a; Huddart \& Hambrey 1996; Hambrey et al. 1997). Freezing on of subglacial sediment leads to its incorporation as sediment rafts within englacial thrusts, which subsequently melt out as undisturbed sediment blocks, a process which can be seen operating at the contemporary ice margin. A range of different sedimentary facies may be incorporated into moraine-mounds, including basal diamictons, glaciofluvial sediments, glaciomarine fjord sediments and well-rounded gravels, although the dominant facies is usually basal diamicton.
The well-rounded gravels also outcrop as linear ridges on the glacier forefields, particularly at Midtre Lovénbreen and Austre Brøggerbreen. The ridges can be traced as continuous ridges over $50 \mathrm{~m}$ and up to $0.5 \mathrm{~m}$ high (Fig. 3C) and they have been shown to cut through small esker ridges (Fig. $3 \mathrm{~A}$ and $\mathrm{B}$ ). They cut unconformably through diamicton, glaciofluvial gravel and supraglacial sediment and are interpreted as an expression of linear thrusts which elevated the well-rounded gravels within a former ice margin (Bennett et al. 1996a; Hambrey et al., 1997). Modern examples of this process can be seen at the margins of Midtre Lovénbreen, Austre Brøggerbreen and Botnfjellbreen (Fig. 4A) where well-rounded gravels are melting out from linear, englacial thrusts (Fig. 4B). The sediment forms an icecored, ridge morphology, and as the ice slowly melts out, the ridge maintains its integrity as a continuous feature.

The occurrence of well-rounded gravels in this environment is therefore linked to thrusting within 

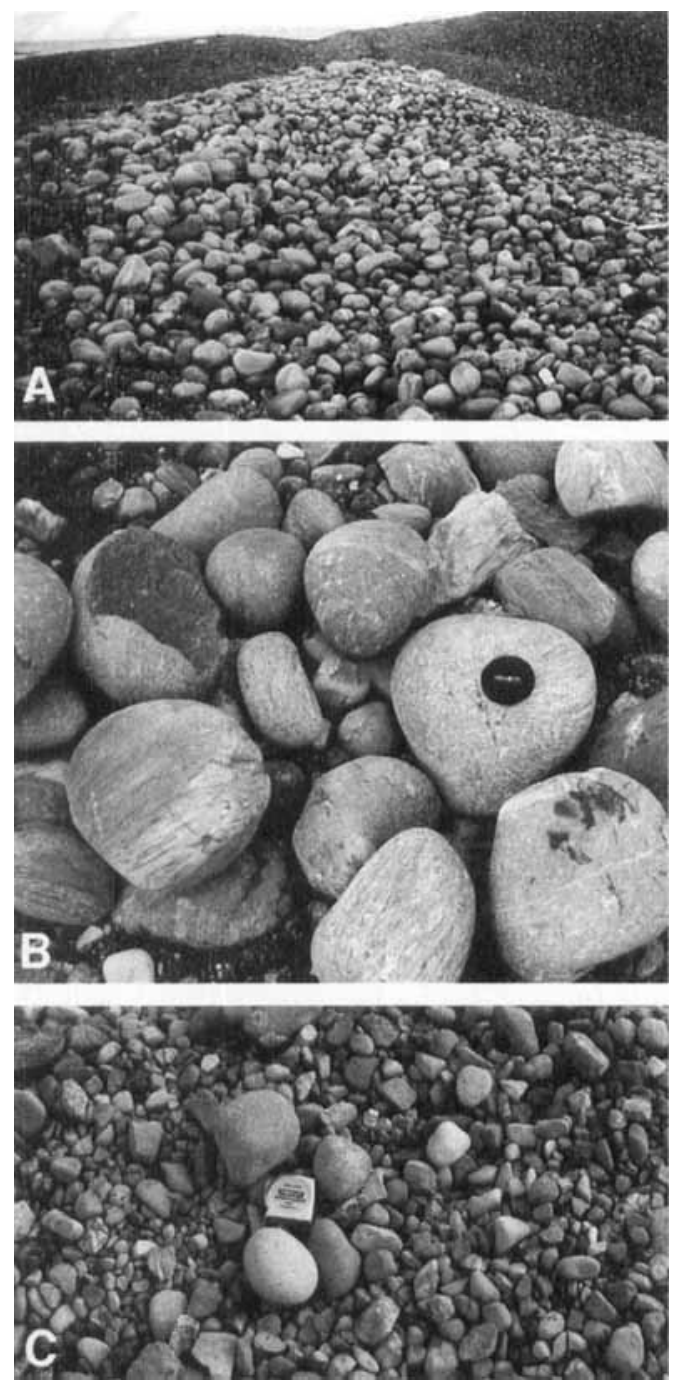

Fig. 2. Well-rounded gravels and raised beach gravels. A. Wellrounded gravels, Midtre Lovénbreen. The gravels are largely composed of augen gneiss. Scale shown by spade. B. Wellsorted and rounded cobble gravels. Midtre Lovénbreen. C. Raised beach gravel at $50 \mathrm{~m}$ a.s.l. at Stuphallet. One location for Early Weichselian beach gravel samples in the particle shape diagrams.

glacier ice which elevates basal debris into an englacial and supraglacial position within the glacier. The origin of this sediment therefore must represent a subglacial or englacial facies and could be derived from a subglacial or englacial process involving ice, or subglacial or englacial fluvial transport. Alternatively, the sediments could be eroded from pre-existing sediments, such as a fluvial or marine gravel, over which the glacier was advancing. In an attempt to explore the origin of these gravels, their clast shape characteristics have been investigated and compared with clast shapes typical of the range of sedimentary environments encountered on Brøggerhalvøya. These include subglacial diamicton, subglacial esker, sandur, modern beach and Early Weichselian beach.

\section{Clast shape analysis and data}

Samples containing 50 clasts were collected from each sedimentary facies encountered in the proglacial, subglacial and ice-marginal zones of the glaciers. In addition, modern beach gravels were sampled from the shore of Kongsfjorden and from Early Weichselian beaches (at $50 \mathrm{~m}$ a.s.l.) outside the maximum Weichselian ice limit at Stuphallet (Fig. 2C) on Brøggerhalvøya described by Miller (1982), Miller et al. (1989) and Lehman \& Forman (1992). A total of 172 samples ( 8600 clasts) were collected. For each clast the following information was obtained: (1) the length of the three orthogonal axes (a, b and c), and (2) a visual estimate of particle roundness recorded both as a Powers' (1953) roundness class and as a Krumbein (1941) roundness number in order to record the full spectrum of variation within each roundness class (very angular 0.0-0.17; angular $0.17-0.25$; subangular $0.25-0.35$; subrounded $0.35-0.49$; rounded $0.49-0.7$; well rounded $0.7-1.0)$. The data is analysed in detail in Bennett et al. (1997), but here we focus on the characteristics of the well-rounded gravels.

The well-rounded gravels can be distinguished on the basis of particle roundness from all the samples, except the Early Weichselian beaches (Fig. 5). This point is reinforced in Fig. 6 which shows the mean and range in roundness values for a number of typical samples. This plot shows that there is a lack of distinction in roundness for most of the subglacial facies, as noted by Bennett et al. (1997). For example, basal diamictons cannot be distinguished from glaciofluvial deposits, including esker gravels. They can, however, be distinguished from supraglacial sediments which are significantly more angular as would be 

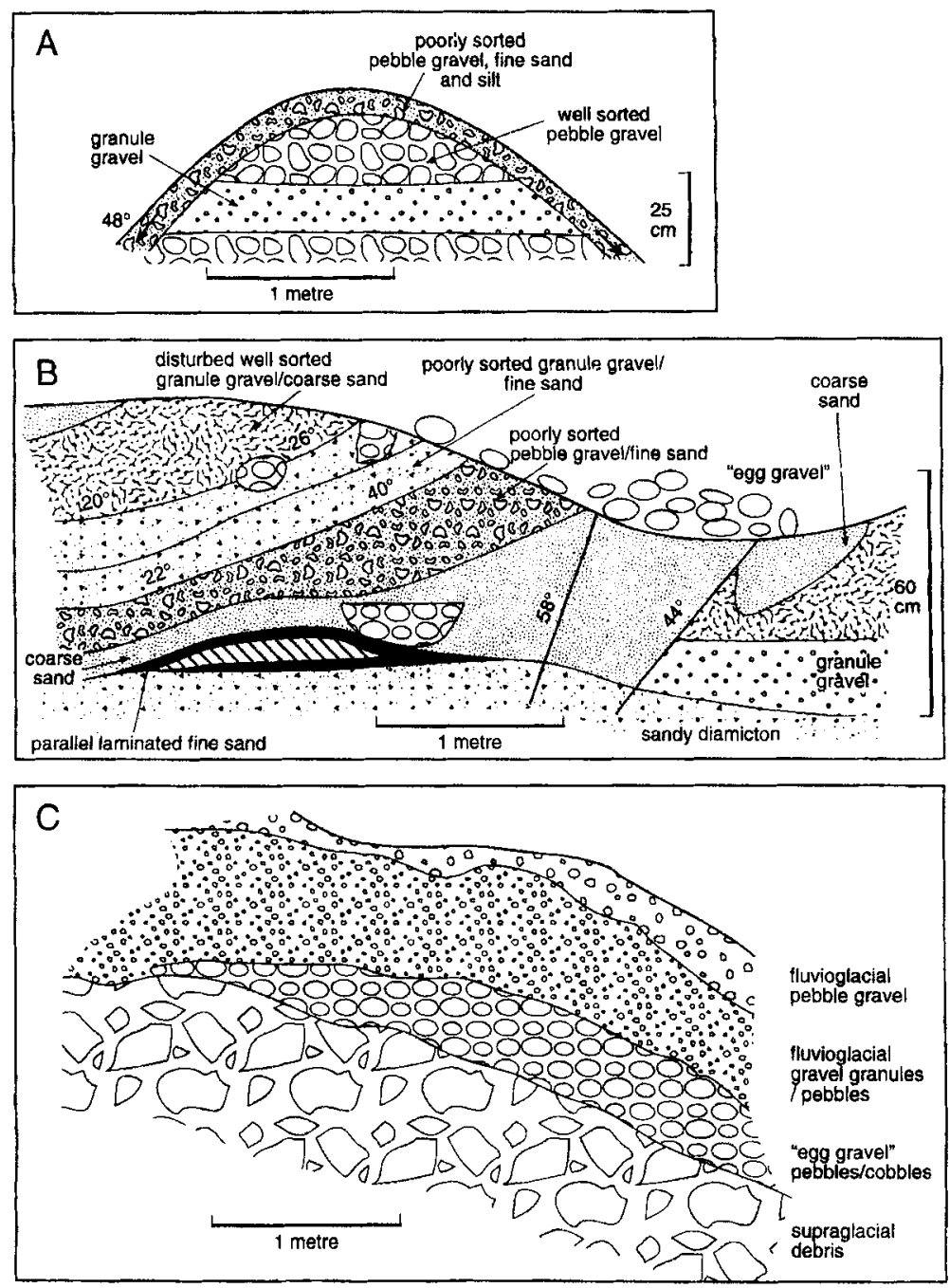

Fig. 3. Thrusts cutting through the Midtre Lovénbreen forefield. A. Small esker and its stratigraphy. B. Esker sediments cut through by thrusting at a high angle which brings well-rounded gravels to the surface in places. C. Wellrounded gravels within glaciofluvial and supraglacial sediment

expected (Boulton 1978; Benn \& Ballantyne 1994). The subglacial facies is also very similar to modern beach sediments which is not surprising since the beach sediments are largely reworked from basal diamictons and outwash sediments. However, the modern beach samples are very distinct from the Early Weichselian raised beach gravels sampled, which are similar in roundness to the well-rounded gravels. Co-variant plots of roundness and sphericity reinforce the similarities between well-rounded gravels and the Early Weichselian raised beach gravels and their mutual distinction from the other facies sampled, which are indistinguishable on this type of plot (Fig. 7).

\section{Discussion}

There are three major points which need discussion. These are the origin of the well-rounded gravels, the greater roundness of the Early Weichselian raised beach gravels with respect to modern beach gravels, and the importance of sediment re-working and the potential problems that this can cause in the correct interpretation of a glacial sedimentary facies.

\section{The origin of the well-rounded gravels}

Clues as to the origin of these sedimentologically distinctive, well-rounded gravels have largely 
Fig. 4. Thrusts and wellrounded gravels at Midtre Lovénbreen. A. Thrusting in an ice frontal location. Most of the gravel is glaciofluvial in origin but some is well-rounded gravel, as in Fig. 4B.
B. Well-rounded gravel from a thrust ridge, similar to Fig. $4 \mathrm{~A}$. Note the angular, supraglacial sediment adjacent to the thrust ridge.
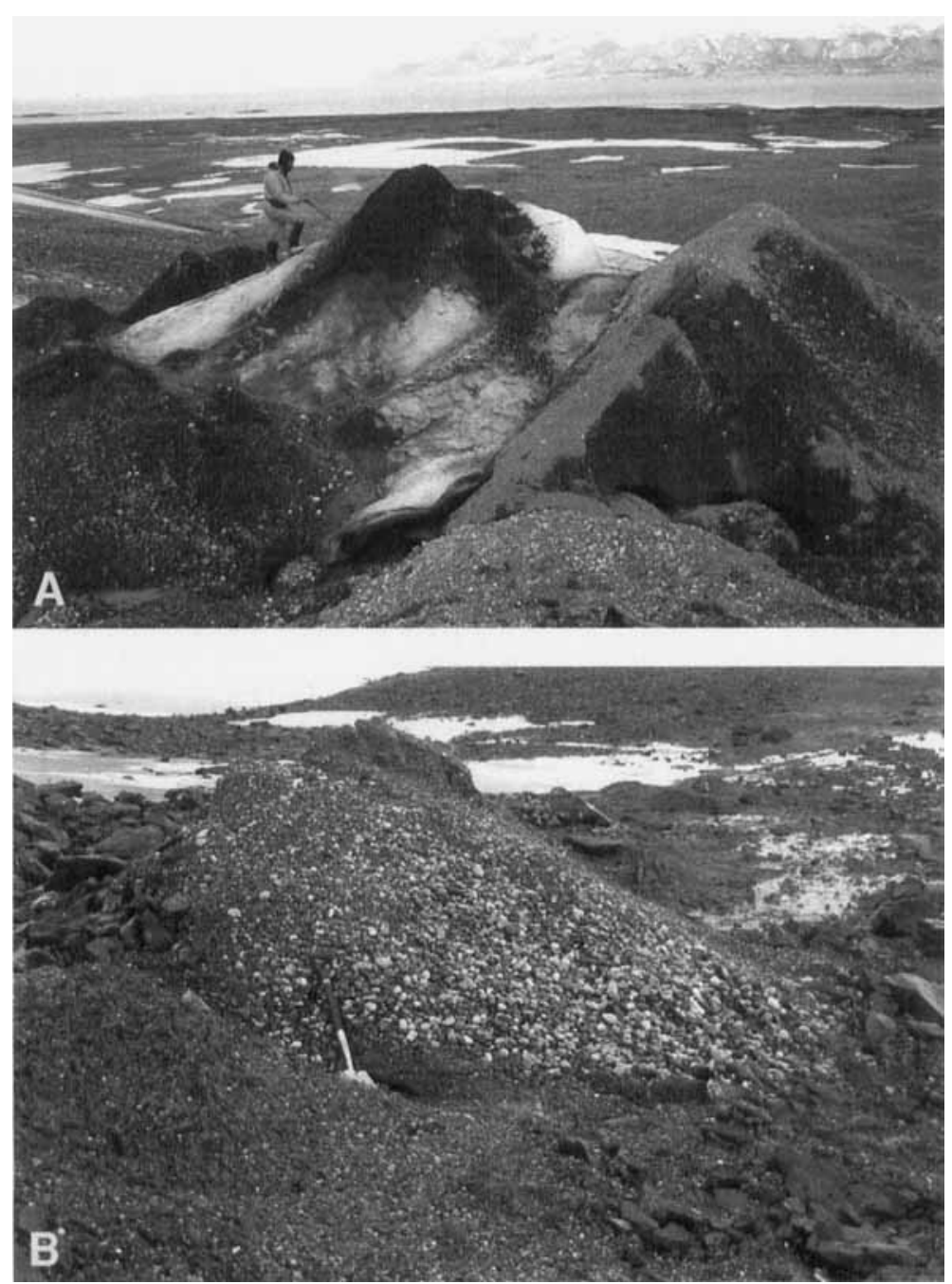

come from the clast characteristic work. It has been shown that they occur within the moraine mounds, in the recent glacier forefields and as modern englacial thrusts in all of the valley glaciers on the north side of Brøggerhalvøya, from Austre Brøggerbreen in the west, to Botnfjellbreen in the east (Fig. 1). None have yet been observed at any of the glaciers on the south side of this peninsula, despite sedimentological work on these glaciers (Hambrey \& Huddart, 1995; Huddart \& Hambrey 1996). Their current morphological expression is the result of thrusting from a subglacial position, followed by subsequent meltout from the ice. The clast shape data presented in this paper suggest that the most likely source for these well-rounded gravels is Early Weichselian beaches which are currently found on Brøggerhalvøya but to the west of the glaciers investigated.

However, Brossard \& Joly (1986) attributed the occurrence of well-rounded gravels at Midtre Lovénbreen to a subglacial meltwater network. This seems unlikely as the clast-shape data presented above for esker gravels at Midtre 

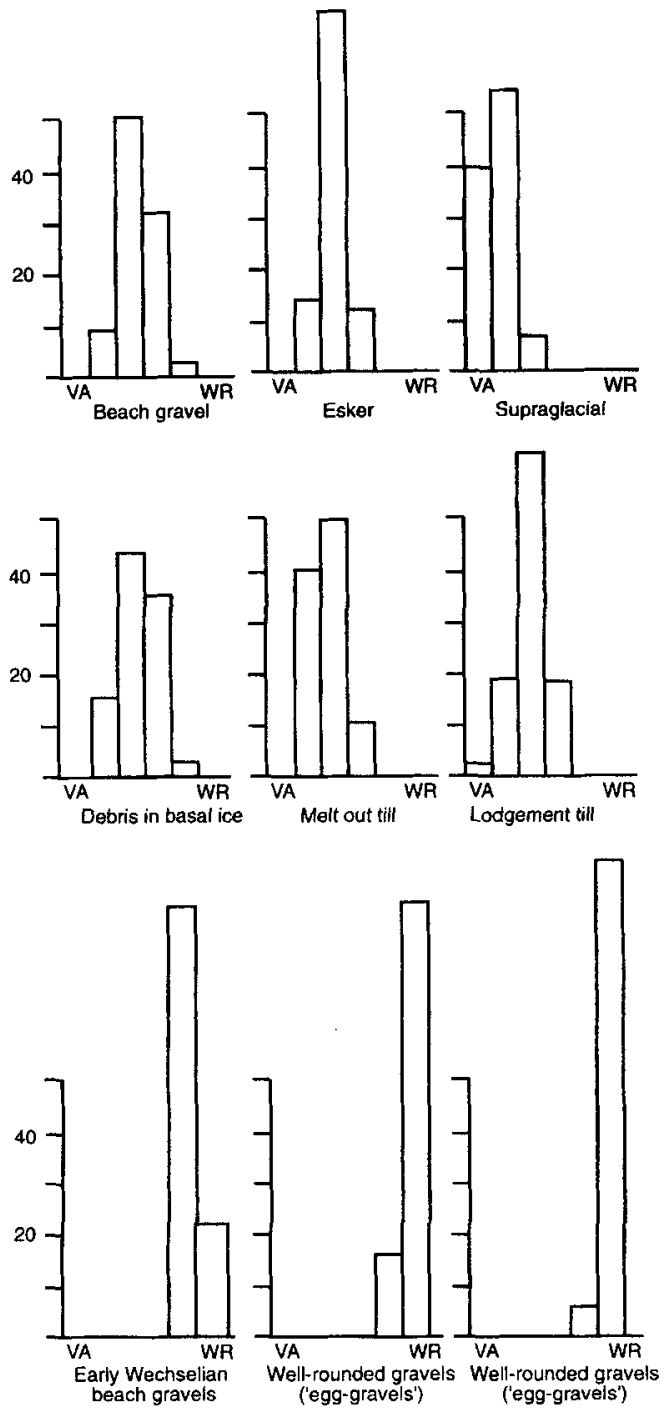

Fig. 5. Percentage frequency histograms of roundness class (very angular. angular, subangular, subrounded, rounded and well-rounded) for well-rounded gravels, Early Weichselian beach gravels, modern beach gravel and some of the glacial facies sampled. Each sample contains 50 clasts.

Lovénbreen, Pedersenbreen and Comfortlessbreen do not possess such high roundness values. A derivation from an Early Weichselian or Eemian raised beach seems much more plausible. High beaches are present on the peninsula. For example, Lefauconnier (1987) noted a beach at $83 \mathrm{~m}$ at the foot of Zeppelinfjellet, east of Austre Brøggerbreen (Fig.1 ), and in Barbaroux (1966) and Moign (1974) there are reports of another beach at $80-85 \mathrm{~m}$ at the base of Slattôfjell, between Austre and Midtre Lovénbreen (Fig. 1). As the Late Weichselian marine limit occurs at $45 \mathrm{~m}$ on Brøggerhalvøya (Forman \& Miller 1984; Forman et al. 1987), it is likely that the higher beach noted by these authors indicates at least an age as old as the last interglacial, possibly the Leinstranda Interglacial, or episode C (Eemian) of Miller (1982) and Miller et al. (1989). This interglacial has been correlated with isotope substage $5 \mathrm{e}$ at approximately $122,000 \pm 6000$ BP (Martinsson et al. 1987). The higher beach samples for clast-shape analysis reported here came from an altitude of $50 \mathrm{~m}$ a.s.l. (measured by altimeter), outside the supposed Weichselian ice limits, although this limit is still debated. Hence these beach gravels are likely to be Early Weichselian in age (Episode B of Miller et al. (1989). Forman \& Miller (1984) suggested that beaches between $44 \mathrm{~m}-55 \mathrm{~m}$ should be tentatively correlated with sea levels in the period 60-160 ka, and Miller et al. (1989) suggested an age of $70 \pm 10 \mathrm{ka}$. The age in the latter paper was based on a radiocarbon date of $>62.5 \mathrm{ka}$ on intact collagen from whalebone preserved in frozen Episode B littoral sediments and in addition two U-series dates on bone from this level indicate an age of about $70 \mathrm{ka}$. Miller et al. (1989) also state that the glaciation preceding Episode $\mathrm{B}$ was smaller than the one preceding Episode $C$, yet the former is interpreted to have been regional in character. However, this is still debated, as are the ice limits for the Late Weichselian. Yet an age of $70 \mathrm{ka}$ for the initial deposition of the well-rounded gravels would explain their localised occurrence and their presence in all the thrust moraine-mound complexes on the northern side of Brøggerhalvøya. The well-rounded gravels in the glacial sediments could nevertheless be reworked also from beach gravels from the older Episode $\mathrm{C}$ in the inner parts of Kongsfjorden. The fact that the well-rounded gravels have not been located on the southern side of the peninsula might indicate a difference in glacier accumulation and glacier growth during the Late Weichselian and/or the Little Ice Age and be evidence of localised events concentrated on the northern side of the peninsula. It equally well could be that further work on the south side might yet locate such well-rounded gravels. Further work on the significance of the well-rounded gravel distribution needs to be carried out and cannot be considered here. 
Fig. 6. Plot of mean roundness and roundness range for the well-rounded gravels, Early Weichselian and modern beach gravels and some glacial facies. Each sample contains 50 clasts.
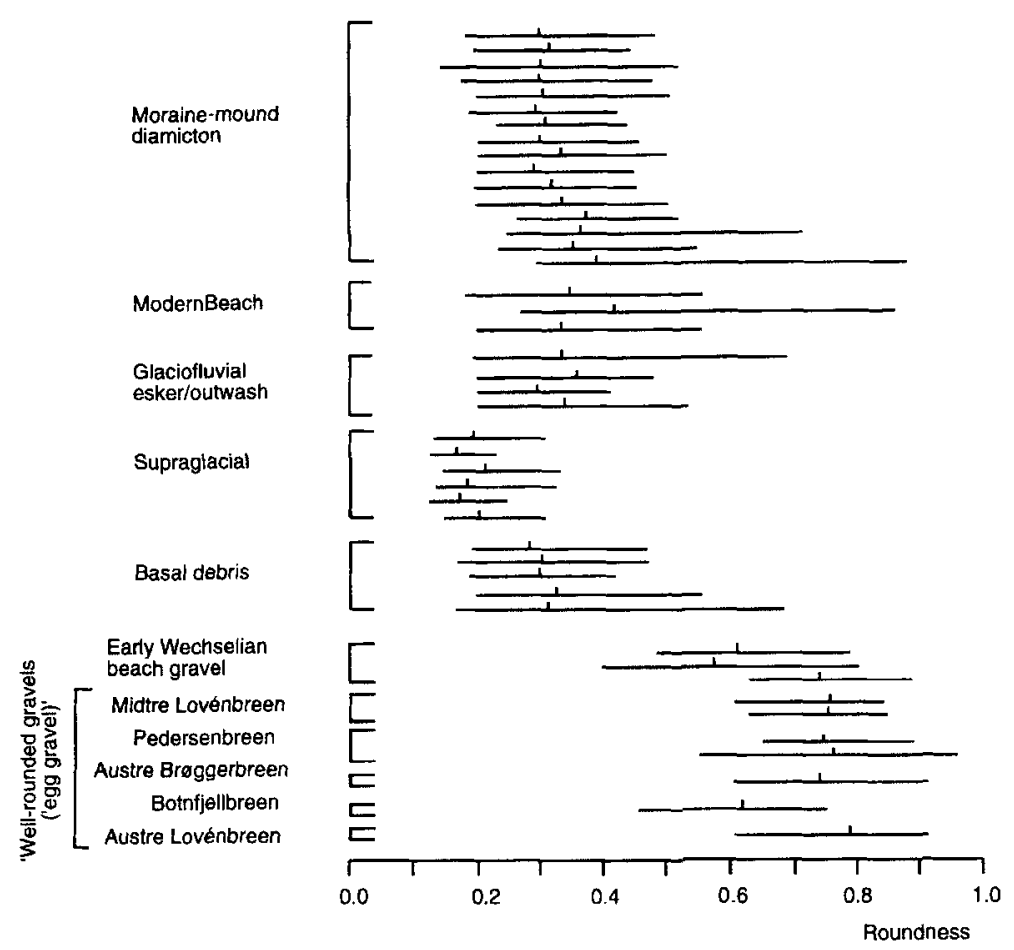

The importance of sediment reworking and the problems this can cause in the correct interpretation of glacial facies

Sediment reworking has not been fully considered as a problem in the interpretation of glacial facies in the past but it has to be taken into consideration before the correct history of a sediment is fully understood. The example of the well-rounded gravels illustrates that an obvious, anomalous sediment type within the glacial facies will be easily recognised and interpreted, but some sediments which might not be so markedly different would be difficult to recognise, or would have remained unrecognised. For example, if the glaciers advanced over the proglacial outwash and modern beaches around Kongsfjorden, they would incorporate sediment from these environments which would be difficult to accurately place in the correct, original sedimentary facies. It is doubtful if clast shape characteristics would allow such subtle distinctions. In clast shape studies, therefore, these sediments would have the potential to 


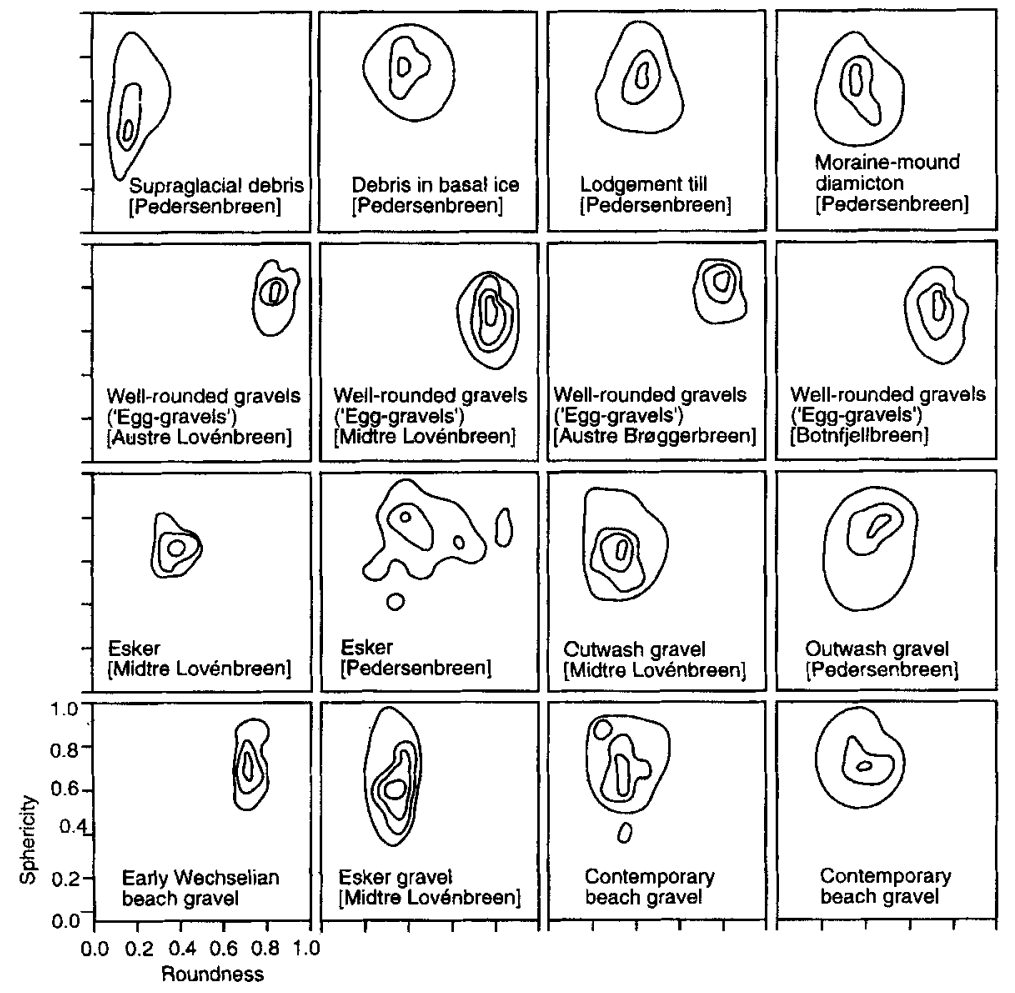

Fig. 7. Sphericity versus roundness plots for the wellrounded gravels and other sampled facies. Point densities are contoured at $1,3,5$ and $7 \%$ per $100 \%$ area. Each sample contains 50 clasts. bias the results and possibly limit their usefulness in such circumstances. This work from Brøggerhalvøya acts as a warning wherever clast shape comparisons are made to a modern glacial environment from unknown sediments. In the Pleistocene, where there could have been multiple reworking and recycling of glacial, glaciofluvial and marine sediments, the task of differentiating sediments based on clast shape characteristics becomes very difficult. Kirkbride (1995) reinforces this point in discussing particle shape evolution where he stresses that "great caution must therefore be used in discriminating between different glacial environments solely upon particle shape and roundness."

In general the possible inheritance of clast shape characteristics from earlier deposits (reworking) presents a difficult problem which calls for careful interpretation of results. It may not always be evident that the problem exists, although Fisher \& Bridgland (1986) suggested that the oceurrence of a bimodal or polymodal distribution of morphological indices may suggest that reworking has occurred. Dreimanis (1976) too recognised that local reworking of older strata in deformation till may completely dominate an assemblage, obscuring a smaller regional component and therefore hindering interpretation.

Nevertheless, despite the cautionary warning with regard to the interpretation of reworked sediments, the value of clast shape as a discriminator of depositional environments has proved to be important in deciding the likely origin of these gravels.

\section{Conclusions}

The morphological expression of well-rounded gravels associated with high-arctic valley glaciers in Spitsbergen has suggested that they were formed by englacial thrusting of subglacial sediment, followed by melting out to form moraine-mound complexes, or smaller thrust ridges. Clast shape data from these well-rounded 
gravels, from modern glacial and beach environments, and from Early Weichselian beaches, suggests that the well-rounded gravels are not associated with any of the glacial facies and were most likely to have originated on a high energy beach in an ice-free fjord over a long period of time, probably well in excess of ten thousand years. This was likely to be during the period $70-125 \mathrm{ka}$ when sea levels ranged from 50 to $80 \mathrm{~m}$ a.s.l. (Miller et al. 1989). The best discriminators for the well-rounded gravels are the roundness histogram, the mean roundness and the roundness range diagrams and the plots of sphericity versus roundness. The modern beach gravels cannot be distinguished from the basal diamictons and outwash sediments from which they have been reworked comparatively recently. Reworking is potentially a major problem when clast shape comparisons to modern glacial environments are made from older unknown sediments. The types of reworking problems outlined in this paper must always be considered as likely in a glacial sequence and that the correct interpretation based solely on clast shape studies is often difficult.

Acknowledgements. - Financial support towards fieldwork costs from the Royal Society (1992), NERC (1996, Grant GR 9/02185), the University of Greenwich $(1995,1996)$ and Liverpool John Moores University $(1992,1994,1995,1996)$ is gratefully acknowledged. The logistical support of N. Cox and the NERC Arctic Research Station was essential to this project. $T$. Andersson and an anonymous referee improved the manuscript considerably.

\section{References}

Barbaroux, L. 1966: L'Étude statistique des blocks erratiques, rive Sud du Kongsfjord. Rapport de la R.C.P. 42 du CRNS.

Benn, D. I. \& Ballantyne, C. K. 1994: Reconstructing the transport history of glacigenic sediments: a new approach based on the co-variance of clast form indices. Sediment. Geol. 91, 215-227.

Bennett, M. R., Huddart, D., Hambrey, M. J. \& Ghienne, J. F. 1996a: Moraine development at the high-arctic valley glacier Pedersenbreen. Svalbard. Geograf. Ann. 78A, 209-222.

Bennett, M. R., Hambrey, M. J., Huddart, D. \& Ghienne, J. F. 1996b: The formation of geometrical ridge networks ("crevasse-fill ridges"), Kongsvegen, Svalbard. J. Quat. Sci. 11, 437-449.

Bennett, M. R., Hambrey, M. J. \& Huddart, D. 1997; Modification of clast shape in high-arctic glacial environments. J. Sediment. Res. 67, 550-559.
Boulton, G. S. P. 1978: Boulder shapes and grain-size distributions of debris as indicators of transport paths through a glacier and till genesis. Sediment. 25, 773-799.

Brossard, Th. \& Joly, D. 1986: Recherches Franç̧aises au Svalbard. Cahier de Geog. de Besancon No. 2.

Dreimanis, A. 1976: Tills: their origin and properties. Pp. 11-49 in Legget, R. F. (ed.): Glacial till. An interdisciplinary study. Royal Soc. Can. Spec. Publ, 12.

Fisher, P. F. \& Bridgland, D. F. 1986: Analysis of Pebble Morphology. In Bridgland, D. F. (ed.): Clast Lithological Analysis, Quatemary Research Association Technical Guide No. 3. Quaternary Research Association, Cambridge.

Forman. S. L. \& Miller, G. H. 1984: Time-dependent soil morphologies and pedogenic processes on raised beaches, Brøggerhalvøya, Spitsbergen, Svalbard Archipelago. Arct. Alp. Res. 16, 381-394.

Forman, S. L., Mann, D. H. \& Miller, G. H. 1987: Late Weichselian and Holocene relative sea-level history of Brøggerhalvøya, Spitsbergen. Quat. Res. 27, 41-50.

Hambrey, M. J. \& Huddart, D. 1995: Englacial and proglacial glaciotectonic processes at the snout of a thermally complex glacier in Svalbard. J. Quat. Sci. 10, 313-326.

Hambrey, M. J., Bennett, M. R., Huddart, D. \& Glasser, N. 1997: Genesis of "hummocky moraine" by thrusting in glacier ice: evidence from Svalbard and Britain. $J$. Geol. Soc. Lond. 154, 623-632.

Huddart, D. \& Hambrey, M. R. 1996: Sedimentary and tectonic development of a high-arctic, thrust-moraine complex: Comfortlessbreen, Svalbard. Boreas 25, 227-243.

Kirkbride, M. J. 1995: Processes of Transportation, Chapter 8. Pp. 261-292 in Menzies, J. (ed.): Modern Glacial Environments: processes, dynamics and sediments. ButterworthHeinemann, Oxford

Krumbein, W. C. 1941: Measurement and significance of shape and roundness of sedimentary particles. J. Sediment. Petrol. $11,64-72$.

Lefauconnier, B. 1987: Fluctuations glaciares dans le Kongsfjord (Baie du Roi), $79^{\circ} \mathrm{N}$, Spitsbergen, Svalbard-analyse et consequences. Unpubl, thesis of the Université de Grenoble.

Lehman, S. J. \& Forman, S. L. 1992: Late Weichselian Glacier Retreat in Kongsfjorden, West Spitsbergen, Svalbard. Quat. Res. 37, 139-154.

Martinsson, D. G., Piseas, N. G., Hays, J. D., Imbrie, J. I., Moore, T. C. Jr \& Shackieton, N. J. 1987: Age dating and orbital theory of the ice ages: development of a highresolution 0 to 300,00-years chronostratigraphy. Quat. Res. 27, 1-29.

Miller, G. H. 1982: Quaternary depositional episodes, Western Spitsbergen, Norway: aminostratigraphy and glacial history. Arct. Alp. Res. 14, 321-340.

Miller, G. H., Sjerup, H. P., Lehman, S. J. \& Forman, S. L. 1989: Glacial history and marine environmental change during the last interglacial-glacial cycle, western Spitsbergen. Svalbard. Boreas 18, 273-296.

Moign. A. 1974: Strandflats immerges et emerges du Spitsberg. central et Nord-Occidental. Unpubl. thesis of the Universite de Bretagne Occidental.

Powers, M. C. 1953: A new roundness scale for sedimentary particles. J. Sediment. Petrol. 23, 117-119.

Sollid. J. L. \& Sørbel. L. 1988: Influence of temperature conditions in formation of end moraines in Fennoscandia and Svalbard. Boreas 17, 553-558. 